\title{
Teaching NeuroImages: Congenital membrane causing unilateral hydrocephalus
}

Vadivalagianambi Sivakumar, MD, and Venkatraman Indiran, MD, DNB

Neurology ${ }^{\circledR}$ 2018;90:e440-e441. doi:10.1212/WNL.0000000000004889

Correspondence

Dr. Indiran

ivraman31@gmail.com

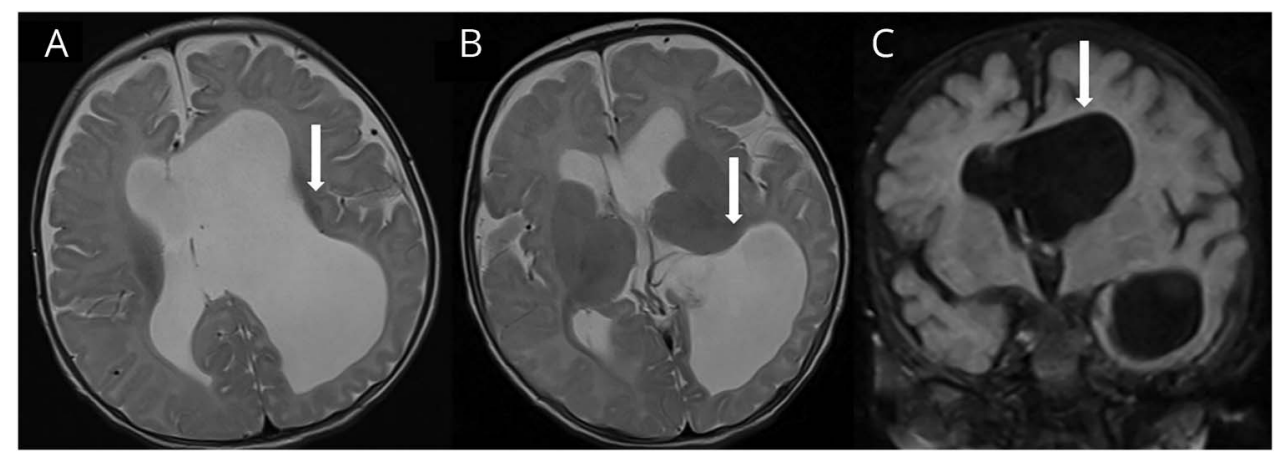

Axial T2-weighted images $(A, B)$ and coronal T1-weighted image (C) show univentricular hydrocephalus involving the left lateral ventricle (arrows).
A 4-month-old afebrile baby boy was brought in with a history of 2 absence seizure-like episodes since birth. MRI brain revealed unilateral hydrocephalus involving left lateral ventricle (figure 1). Thin coronal and sagittal T1-weighted images showed membrane obstructing left foramen of Monro (figure 2).

Unilateral hydrocephalus is caused by foramen of Monro obstruction due to neoplastic or inflammatory causes and congenital atresia or membrane occluding foramen. ${ }^{1}$ Thalamic or intraventricular tumors and tuberculous ventriculitis/ependymitis may cause obstruction. Corpus callosal abnormalities are the commonest association with congenital foraminal

\section{MORE ONLINE}

\section{$\rightarrow$ Teaching slides:}

links.lww.com/WNL/A95

Figure $2 \mathrm{MRI}$ shows membrane obstructing left foramen of Monro

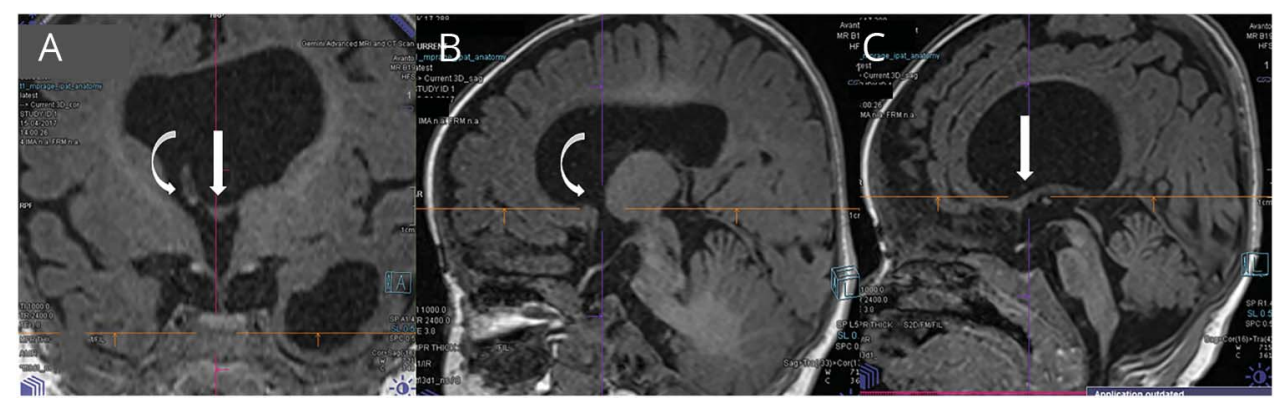

(A) Coronal T1-weighted image shows univentricular hydrocephalus involving the left lateral ventricle with membrane obstructing left foramen of Monro (straight white arrow). Curved white arrow shows patent right foramen of Monro. Curved arrow in (B) shows patent right foramen of Monro on sagittal T1 weighted image. Straight white arrow in (C) shows membrane obstructing left foramen of Monro on sagittal T1-weighted image.

From Gemini Scans (V.S.), Chennai; Department of Radiodiagnosis (V.S.), Meenakshi Medical College Hospital \& Research Institute; and Department of Radiodiagnosis (V.I.), Sree Balaji Medical College and Hospital, Tamilnadu, India.

Go to Neurology.org/N for full disclosures. Funding information and disclosures deemed relevant by the authors, if any, are provided at the end of the article. 
membrane. Surgical options include shunting dilated ventricle, septum pellucidum fenestration, and neuroendoscopic fenestration of occluded foramen. ${ }^{2}$ Final diagnosis of unilateral hydrocephalus due to congenital membrane in foramen of Monro was considered and the patient is awaiting shunt placement.

\section{Author contributions}

V. Sivakumar: study concept and analysis and interpretation of data. V. Indiran: study concept and analysis and interpretation of data.

\section{Study funding}

No targeted funding reported.

\section{Disclosure}

The authors report no disclosures relevant to the manuscript. Go to Neurology.org/ $\mathrm{N}$ for full disclosures.

\section{References}

1. Kumar R. Unilateral hydrocephalus in paediatric patients, a trial of endoscopic fenestration. Neurol India 1999;47:282-285.

2. Nigri F, Gobbi GN, da Costa Ferreira Pinto PH, Simões EL, Caparelli-Daquer EM. Hydrocephalus caused by unilateral foramen of Monro obstruction: a review on terminology. Surg Neurol Int 2016;7(suppl 12):S307-S313. 


\section{Neurology}

\section{Teaching NeuroImages: Congenital membrane causing unilateral hydrocephalus}

Vadivalagianambi Sivakumar and Venkatraman Indiran

Neurology 2018;90;e440-e441

DOI 10.1212/WNL.0000000000004889

This information is current as of January 29, 2018

\section{Updated Information \& Services}

References

Subspecialty Collections

Permissions \& Licensing

Reprints including high resolution figures, can be found at: http://n.neurology.org/content/90/5/e440.full

This article cites 2 articles, 0 of which you can access for free at: http://n.neurology.org/content/90/5/e440.full\#ref-list-1

This article, along with others on similar topics, appears in the following collection(s):

All Epilepsy/Seizures

http://n.neurology.org/cgi/collection/all_epilepsy_seizures MRI

http://n.neurology.org/cgi/collection/mri

Information about reproducing this article in parts (figures,tables) or in its entirety can be found online at:

http://www.neurology.org/about/about_the_journal\#permissions

Information about ordering reprints can be found online:

http://n.neurology.org/subscribers/advertise

Neurology ${ }^{\circledR}$ is the official journal of the American Academy of Neurology. Published continuously since 1951, it is now a weekly with 48 issues per year. Copyright @ 2018 American Academy of Neurology. All rights reserved. Print ISSN: 0028-3878. Online ISSN: 1526-632X.

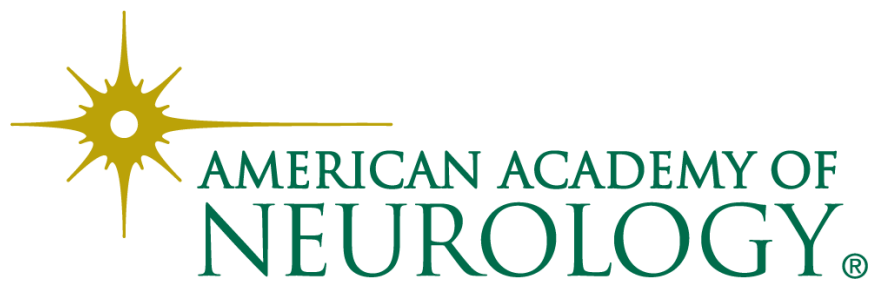

